\section{Synthesis of isoxazoles by hypervalent iodine-induced cycloaddition of nitrile oxides to alkynes $\dagger$}

\author{
Anup M. Jawalekar, Erik Reubsaet, Floris P. J. T. Rutjes and Floris L. van Delft* \\ Received 27th October 2010, Accepted 6th January 2011 \\ DOI: $10.1039 / \mathrm{c0cc04646a}$
}

Treatment of oximes with hypervalent iodine leads to substituted isoxazoles via rapid formation of nitrile oxides. Reaction with terminal alkynes led to a series of 3,5-disubstituted isoxazoles with complete regioselectivity and high yield, in a procedure mild enough to prepare a range of nucleoside and peptide conjugates. Exceptionally high reaction rates were found for the formation of 3,4,5-trisubstituted isoxazoles from a cyclic alkyne.

Isoxazoles form a major class of nitrogen heterocycles that are molecular components in a variety of natural products (e.g. ibotenic acid, muscimol, isoxazole-4-carboxylic acid) and drugs (e.g. valdecoxib, leflunomide, cloxacillin). ${ }^{1} \mathrm{~A}$ variety of synthetic methods has been developed for the preparation of isoxazoles, ${ }^{2}$ of which the cycloaddition of nitrile oxides and alkynes is probably the most direct. ${ }^{3}$ However, thermal nitrile oxide-alkyne cycloadditions typically give low yields, side-reactions and poor regioselectivity. ${ }^{4}$ Copper(I) and ruthenium(II)-induced preparation of 3,5 - or 3,4-disubstituted isoxazoles has been reported, ${ }^{5}$ but for many applications the use of (toxic) transition metals is undesirable if not prohibited. Therefore, there exists a clear need for metal-free, regioselective synthesis of isoxazoles.

Recently, it was reported that 3,5-disubstituted isoxazolines can be prepared by cycloaddition to olefins and nitrile oxides, generated in situ from oximes with (diacetoxyiodo)benzene (DIB) with catalytic TFA (Scheme 1 , top). ${ }^{6}$ A single example of isoxazole preparation was also given, but the methodology was not further elaborated, presumably as a consequence of
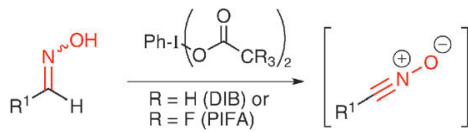

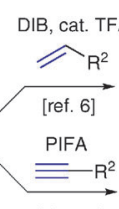

this work
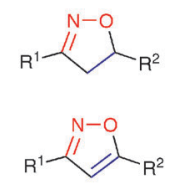

Scheme 1 Cycloaddition of nitrile oxides to alkenes or acetylenes via hypervalent iodine-induced generation of nitrile oxide from oxime.

Institute for Molecules and Materials, Radboud University Nijmegen, Heijendaalseweg 135, NL-6525 AJ, Nijmegen, the Netherlands.

E-mail: F.vanDelft@science.ru.nl; Fax: + 3124 3653393;

Tel: + 31243652373

$\dagger$ Electronic supplementary information (ESI) available: Solvent screening, general synthetic procedures, structural characterisation of oximes and isoxazoles, reaction analysis by NMR and HPLC. See DOI: $10.1039 / \mathrm{c} 0 \mathrm{cc} 04646 \mathrm{a}$ the low yield $(50 \%)$ of the reaction. Herein, we report a methodology for a completely regioselective and high yielding procedure for the preparation of 3,5-disubstituted and 3,4,5-trisubstituted isoxazoles from terminal or cyclic alkynes, respectively. Key to the strategy is near instantaneous generation of nitrile oxides from oximes by use of phenyliodine bis(trifluoroacetate) as an oxidising agent. The versatility of the procedure and applicability as a novel tool for bioconjugation is demonstrated by preparation of a range of nucleoside and peptide-containing isoxazoles. ${ }^{7}$

Due to its low toxicity, ready availability and easy handling, phenyliodine bis(trifluoroacetate) (PIFA) is a useful reagent for oxidative dearomatisation, dehydrodimerisation and selective cyanation. ${ }^{8}$ To date, however, PIFA has not been applied for the generation of nitrile oxide from oximes. We therefore investigated the reaction of phenylacetylene and benzaldoxime under the action of PIFA (ESI $\dagger$ and Table 1). A slow conversion was observed in $\mathrm{MeCN}, i-\mathrm{PrOH}$ or in 1,4dioxane $/ \mathrm{H}_{2} \mathrm{O}(5: 1)$ mixtures but in $\mathrm{MeOH} / \mathrm{H}_{2} \mathrm{O}(5: 1)$, a highly efficient reaction took place. ${ }^{9} \mathrm{~A}$ small excess ( 1.5 equiv.) of oxime is required for the reaction as a result of the fact that the in situ formed nitrile oxide slowly homodimerizes to furoxan or 1,4-dioxo-2,5-diazine. ${ }^{4,10}$ Therefore, the effect of portion-wise addition of PIFA and reaction concentration was investigated (Table 1). When benzaldoxime (1.5 equiv.) and PIFA (1.5 equiv.) were combined with phenylacetylene $(0.01 \mathrm{M})$, the expected 3,5-disubstituted isoxazole was obtained in $65 \%$ yield. Addition of PIFA in two portions (total 1.5 equiv.) improved the yield to $70 \%$. Further increasing the reaction concentration (with respect to alkyne) to $0.1 \mathrm{M}$ and addition of PIFA in three portions over $2 \mathrm{~h}$ intervals

Table 1 Cycloaddition of phenylacetylene and benzonitrile- $N$-oxide<smiles>C#[P+]c1ccccc1</smiles>
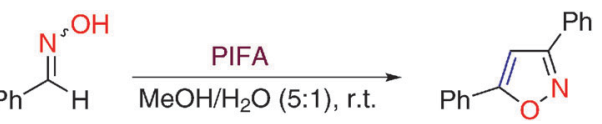

\begin{tabular}{llllll}
\hline Entry & Conc. $^{a} / \mathrm{M}$ & $\begin{array}{l}\text { Oxime } \\
\text { (equiv.) }\end{array}$ & $\begin{array}{l}\text { PIFA addition } \\
(1.5 \text { equiv.) }\end{array}$ & Time $/ \mathrm{h}$ & Yield (\%) \\
\hline 1 & 0.01 & 1.5 & 1 portion & 24 & 65 \\
2 & 0.01 & 1.5 & 2 portions $/ 4 \mathrm{~h}$ & 24 & 70 \\
3 & 0.1 & 1.5 & 3 portions $/ 2 \mathrm{~h}$ & 7 & 90 \\
\multicolumn{7}{l}{ Concentration of phenylacetylene. }
\end{tabular}


( 1.5 equiv. in total), gave the desired isoxazole in $90 \%$ yield after $7 \mathrm{~h}$. The beneficial role of PIFA is explained by the near instantaneous formation (1 min) of nitrile oxide from $p$-methylbenzaldoxime (Fig. S1, ESI $\dagger$ ), while oxidation with DIB is sluggish and incomplete after $60 \mathrm{~min}$ (Fig. S2, ESI $\dagger$ ).

Having established optimal conditions for in situ generation of nitrile oxide, and cycloaddition to acetylene, the scope of isoxazole formation was evaluated for a range of substrates (Table 2). A variety of aromatic or aliphatic oximes or alkynes, with electron-deficient or electron-rich groups, was converted to 3,5-disubstituted isoxazoles in good to excellent yields. Aliphatic alkynes were less reactive than aromatic alkynes giving 55-66\% product based on the oxime used. However, use of four-fold excess of oxime raised the yield to $94 \%$ (entry 16). No competitive cycloaddition of nitrile oxides to olefins was observed in case of trans-cinnamaldoxime (entries 9-12). It must be noted that the yields obtained in our procedure compare favorably to the copper-catalysed synthesis of isoxazoles, especially in case of benzaldoxime (entry 1) and 4-nitrobenzaldoxime (entry 17). ${ }^{5 a, b}$

The scope of nitrile oxide-alkyne cycloaddition for bioconjugation was explored by application to a range of nucleosides and a model peptide (Fig. 1). To our delight, PIFA-induced $(3+2)$ cycloaddition works well with unprotected nucleosides and a $2^{\prime}$-alkyl adenosine-derived ${ }^{11}$ oxime, leading to adducts 21-24, thereby tolerating various functional groups (ESI $\dagger$, Fig. S3). Finally, we successfully prepared an isoxazole from a peptide with an N-terminal acetylene. To this end, freshly generated nitrile oxide from benzaloxime (3 equiv.) in $\mathrm{MeOH}(210 \mu \mathrm{L})$ was added to the peptide $\left(100 \mu \mathrm{M}\right.$ in $\left.\mathrm{H}_{2} \mathrm{O}\right)$, which was repeated six times over $12 \mathrm{~h}$, leading to clean formation of isoxazole ( $>95 \%$ conversion), as confirmed by HPLC and HRMS (Fig. S4, ESI $\dagger$ ).

Having demonstrated the viability of PIFA-induced cycloaddition of nitrile oxides and terminal alkynes, we next investigated strain-promoted reactions with cyclic alkynes, known to undergo rapid cycloadditions with azides ${ }^{12,13}$ and nitrones. ${ }^{14}$ We recently developed a straightforward route to a novel cyclooctyne analogue, namely bicyclo[6.1.0]nonyne (BCN), for metal-free cycloaddition reactions. ${ }^{15}$ In this context, the cycloaddition of $\mathrm{BCN}$ with nitrile oxide could constitute another versatile metal-free ligation strategy. ${ }^{16}$ Thus, a series of aromatic, aliphatic and unsaturated oximes was combined with $\mathrm{BCN}$ (Scheme 2) in $1: 1$ mixture of $\mathrm{MeOH} / \mathrm{H}_{2} \mathrm{O}(0.1 \mathrm{M})$, before oxime and PIFA (each 1.2 equiv.) were added. As expected, the reaction was extremely fast and efficient giving 3,4,5-trisubstituted isoxazoles (compounds 26-34, Scheme 2) in excellent yields within 2-5 min in all cases. Based on NMR experiments $(\mathrm{ESI} \dagger)$, a reaction rate constant of $1.8 \mathrm{M}^{-1} \mathrm{~s}^{-1}$ was determined for benzonitrile- $N$-oxide, a value that compares highly favourably with that of benzyl azide cycloaddition to BCN under identical conditions $\left(0.18 \mathrm{M}^{-1} \mathrm{~s}^{-1}\right)$.

In conclusion, we have demonstrated the use of $\mathrm{PhI}\left(\mathrm{OCOCF}_{3}\right)_{2}$ for the rapid in situ conversion of aldoximes into nitrile oxide and cycloaddition with alkynes. The procedure is experimentally convenient, avoiding the isolation and handling of potentially harmful and unstable hydroximoyl chlorides. The resulting nitrile oxide traps terminal and cyclic alkynes efficiently, in particular in the case of cyclic alkynes, ${ }^{17}$ to give
Table 2 Isoxazoles from terminal alkynes and nitrile oxides

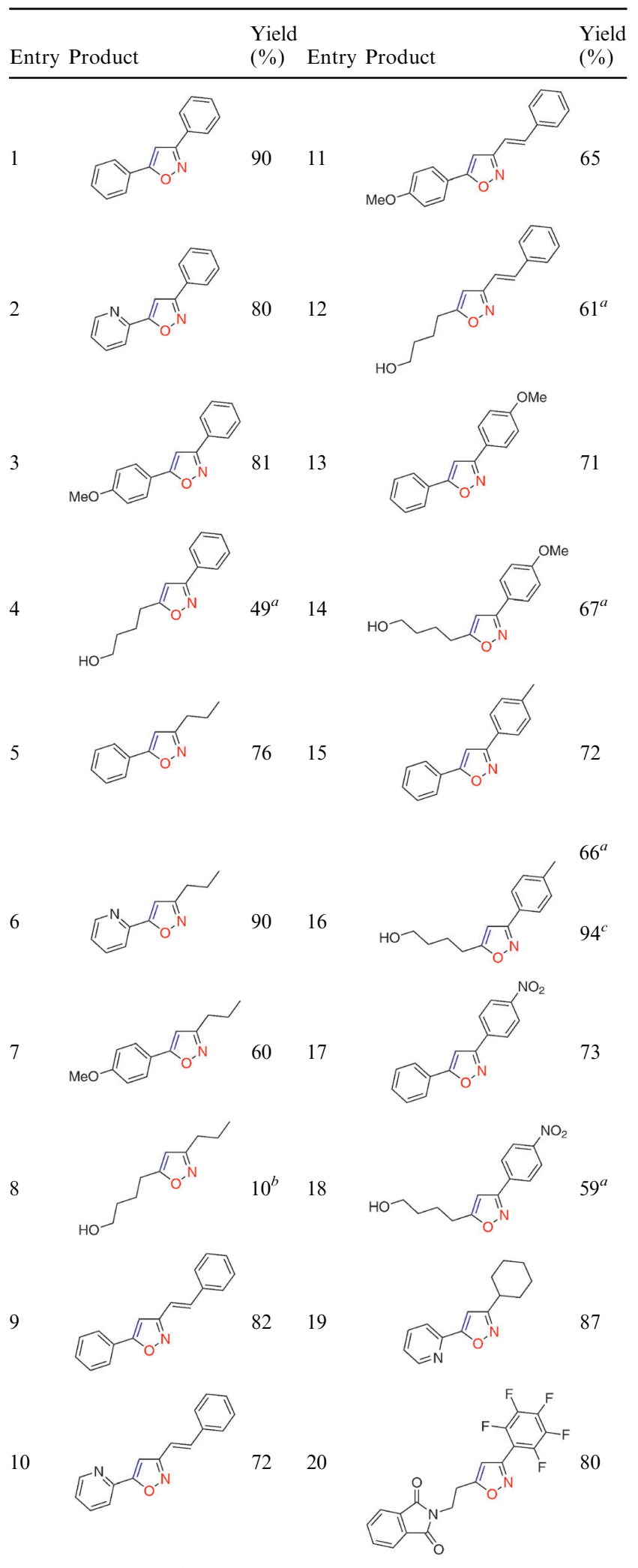

${ }^{a}$ Based on oxime. ${ }^{b}$ Volatile. ${ }^{c} 4$ equiv. oxime used.

3,5-disubstituted and 3,4,5-trisubstituted isoxazoles in high yield. Because no transition metal catalyst is needed and a wide variety of functional groups are tolerated, we foresee high usefulness of 


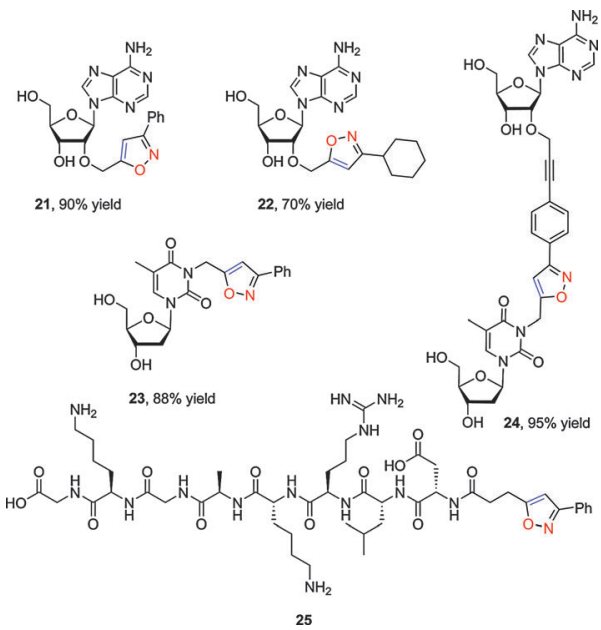

Fig. 1 Nucleoside and peptide-isoxazole conjugates.

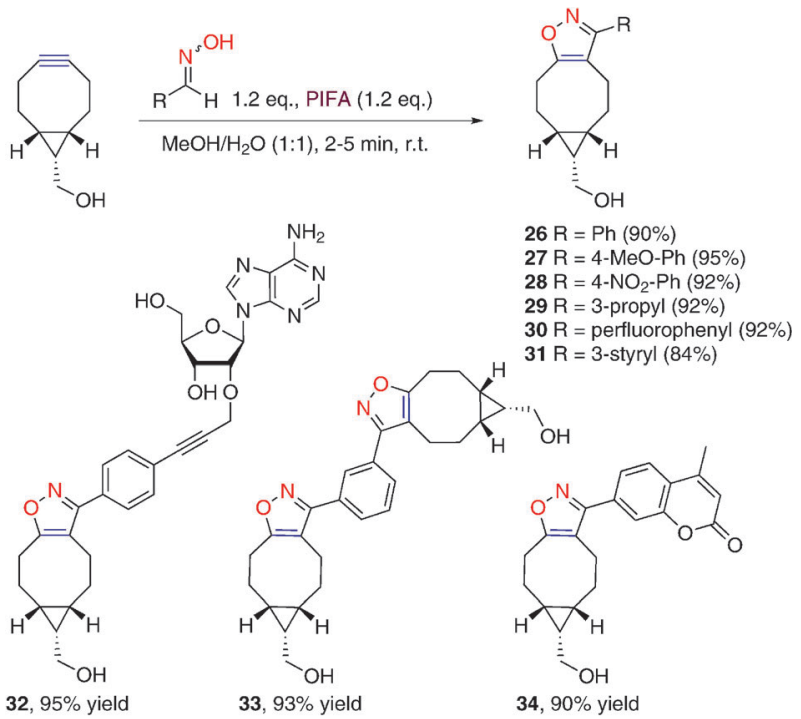

Scheme 2 Nitrile oxide cycloaddition to ring-strained BCN.

our PIFA-mediated synthesis of isoxazoles. ${ }^{18}$ Currently, we are making progress on the application of our approach for labeling of oligonucleotides ${ }^{7 b-d}$ and for nitrile oxide-acetylene cycloaddition to proteins, which may unveil unprecedented ways for metal-free conjugation of proteins containing acetylenes. ${ }^{19}$

We gratefully acknowledge the Netherlands Organisation for Scientific Research (NWO) for financial support (ECHO 07.BM3.038). We thank MSc Morten B. Hansen for his help on the peptide synthesizer and Jan Dommerholt for determination of reaction rate constants.

\section{Notes and references}

1 (a) J. Sperry and D. Wright, Curr. Opin. Drug Discovery Dev., 2005, 8, 723; (b) K. D. Shin, M.-Y. Lee, D.-S. Shin, S. Lee, K.-H. Son, S. Koh, Y.-K. Paik, B.-M. Kwon and D. C. Han, J. Biol. Chem., 2005, 50, 41439; (c) Y.-S. Lee, S. M. Park and B. H. Kim, Bioorg. Med. Chem. Lett., 2009, 19, 1126; (d) B. Rozman, S. Praprotnik, D. Logar, M. Tomsic, M. Hijnik, M. Kos-Golja and P. Dolenc, Ann. Rheum. Dis., 2002, 61, 567; (e) S. L. Lawrence, V. Roth, R. Slinger, B. Toye, I. Gaboury and B. Lemyre, BMC Pediatrics, 2005, 5, 49; $(f)$ K. Kobinata, S. Sekido, M. Uramoto, M. Ubukato, H. Osada, I. Yamaguchi and K. Isono, Agric. Biol. Chem., 1991, 55, 1416.
2 (a) L. Claisen and O. E. Lowman, Ber. Dtsch. Chem. Ges., 1888, 21, 784; (b) A. Kumar, R. A. Maruya, S. Sharma, P. Ahmad, A. B. Singh, A. K. Tamrakar and A. K. Srivastava, Bioorg. Med. Chem., 2009, 17, 5285; (c) Y.-G. Wang, W.-M. Xu and X. Huang, Synthesis, 2007, 28; (d) C. Praveen, A. Kalyanasundaram and P. T. Perumal, Synlett, 2010, 777; (e) M. Mazzei, A. Balbi, E. Sottofattori, R. Garzoglio, A. D. Montis, S. Corrias and P. L. Colla, Eur. J. Med. Chem., 1993, 28, 669; (f) M. Yokoyama, K. Tsuji and M. Kushida, J. Chem. Soc., Perkin Trans. 1, 1986, 67; (g) S. Zen, K. Harada, H. Nakamura and Y. Iitaka, Bull. Chem. Soc. Jpn., 1988, 61, 2881; (h) S. Tang, J. he, Y. Sun, L. He and X. She, Org. Lett., 2009, 11, 3982; (i) J. P. Waldo and R. C. Larock, Org. Lett., 2005, 7, 5203; (j) J. P. Waldo and R. C. Larock, Org. Lett., 2007, 72, 9643.

3 (a) R. Huisgen, 1,3-Dipolar Cycloaddition Chemistry, ed. A. Padwa, Wiley, New York, 1984, vol. 1, p. 1; (b) V. Jaeger and P. A. Colinas, Synthetic Applications of 1,3-Dipolar Cycloaddition Chemistry Towards Heterocycles and Natural Products, ed. A. Padwa, Wiley, Hoboken, 2002, vol. 59, p. 361; (c) S. Dadiboyena, J. Xu and A. T. Hamme II, Tetrahedron Lett., 2007, 48, 1295; (d) S. Beha, D. Giguere, R. Patnam and R. Roy, Synlett, 2006, 1739; (e) N. Maugein, A. Wagner and C. Mioskowski, Tetrahedron Lett., 1997, 38, 1547; (f) T. Mukaiyama and T. Hoshino, J. Am. Chem. Soc., 1960, 82, 5339.

4 (a) T. M. V. D. Pinho e Melo, Curr. Org. Chem., 2005, 9, 925; (b) L. I. Belen'kii, in Nitrile oxides, nitrones and nitronates in organic synthesis, ed. H. Feuer, Wiley, Hoboken, NJ, USA, 2nd edn., 2008.

5 (a) F. Himo, T. Lovell, R. Hilgraf, V. V. Rostovstev, L. Noodleman, K. B. Sharpless and V. V. Fokin, J. Am. Chem. Soc., 2004, 127, 210; (b) T. V. Hansen, W. Peng and V. V. Fokin, J. Org. Chem., 2005, 70, 7761; (c) S. Grecian and V. V. Fokin, Angew. Chem., Int. Ed., 2008, 47, 8285.

6 B. A. Mendelsohn, S. Lee, S. Kim, F. Teyssier, V. S. Aulakh and M. A. Ciufolini, Org. Lett., 2009, 11, 1539.

7 (a) A. Dondoni, P. P. Giovannini and A. Massi, Org. Lett., 2004, 17, 2929; (b) I. Singh, S. J. Vyle and F. Heaney, Chem. Commun., 2009, 3276; (c) K. Gutsmiedl, C. T. Wirges, V. Ehmke and T. Carell, Org. Lett., 2009, 11, 2405; (d) V. Algay, I. Singh and F. Heaney, Org. Biomol. Chem., 2010, 8, 391; (e) I. Singh and F. Heaney, Org. Biomol. Chem., 2010, 8, 451.

8 X.-Y. Han, Synlett, 2006, 2851.

9 The protic solvent(s) may be key in rate enhancement, although opposing effects (hydrophobic, H-bonding, and solvent polarity) make it difficult to denote exactly how. See also: T. Rispens and J. B. F. N. Engberts, J. Phys. Org. Chem., 2005, 18, 908.

10 (a) Z.-X. Yu, P. Caramella and K. N. Houk, J. Am. Chem. Soc., 2003, 125, 15420; (b) D. R. Kelly, S. C. Baker, D. S. King, D. S. de Silva, G. Lord and J. P. Taylor, Org. Biomol. Chem., 2008, 6, 787.

11 A. M. Jawalekar, N. Meeuwenoord, J. S.-G. O. Cremers, H. S. Overkleeft, G. A. van der Marel, F. P. J. T. Rutjes and F. L. van Delft, J. Org. Chem., 2008, 73, 287.

12 (a) N. J. Agard, J. A. Prescher and C. R. Bertozzi, J. Am. Chem. Soc., 2004, 126, 15046; (b) J. M. Baskin, J. A. Prescher, S. T. Laughlin, N. J. Agard, P. V. Chang, I. A. Miller, A. Lo, J. A. Codelli and C. R. Bertozzi, Proc. Natl. Acad. Sci. U. S. A., 2007, 104, 16793; (c) X. Ning, J. Guo, M. A. Wolfert and G.-J. Boons, Angew. Chem., Int. Ed., 2008, 47, 2253.

13 M. F. Debets, S. S. van Berkel, S. Schoffelen, F. P. J. T. Rutjes, J. C. M. van Hest and F. L. van Delft, Chem. Commun., 2010, 46, 97.

14 X. Ning, R. P. Temming, J. Dommerholt, J. Guo, D. B. Ania, M. F. Debets, M. A. Wolfert, G. J. Boons and F. L. van Delft, Angew. Chem., Int. Ed., 2010, 49, 3065.

15 J. Dommerholt, S. Schmidt, R. Temming, L. J. A. Hendriks, F. P. J. T. Rutjes, J. C. M. van Hest, D. J. Lefeber, P. Friedl and F. L. van Delft, Angew. Chem., Int. Ed., 2010, 49, 9422.

16 P. König, J. Zountsas, K. Bleckman and H. Meier, Chem. Ber., 1983, 116, 3580.

17 Reaction of benzonitrile- $N$-oxide (4 equiv.) with acyclic alkynes (diphenylacetylene, 2-butyn-1,4-diol) led to only $\sim 10 \%$ isoxazole.

18 Other applications include reaction with alkynyliodide, see: J. A. Crossley and D. L. Browne, J. Org. Chem., 2010, 75, 5414 or to benzyne, see: A. V. Dubrovskiy and R. C. Larock, Org. Lett., 2010, 12, 1180.

19 (a) E. M. Brustad, E. A. Lemke, P. G. Schultz and A. A. Deniz, J. Am. Chem. Soc., 2008, 130, 17664; (b) A. J. Link and D. A. Tirrell, J. Am. Chem. Soc., 2003, 125, 11164. 